\title{
Social Metabolism and Environmental Conflicts in India
}

\author{
JoAn MARTINEZ-Alier, LEAH TEMPER, FEDERICO DEMARIA \\ ICTA, Universitat Autonòma de Barcelona \\ joanmartinezalier@gmail.com \\ leah.temper@gmail.com \\ federicodemaria@gmail.com
}

Received: 03-09-2013

Accepted: 20-11-2013

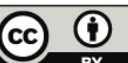

\begin{abstract}
This paper explains the methods for counting the energy and material flows in the economy, and gives the main results of the Material Flows for the economy of India between 1961 and 2008 as researched by Simron Singh et al (2012). Drawing on work done in the EJOLT project, some illustrations are given of the links between the changing social metabolism and ecological distribution conflicts, looking at responses in Odisha to bauxite mining, at conflicts on sand mining, at disputes on waste management options in Delhi and at ship dismantling in Alang, Gujarat. The aim is to show how a history of social metabolism, of socio-environmental conflicts, and of the changing valuation languages deployed by various social actors in such conflicts, could be written in a common framework.
\end{abstract}

KEYWORDS: Economic Growth; Material Flows; Bauxite Mining; Sand Mining; Ship Dismantling; Urban Waste Disposal; Environmental Movements

RESUMEN El metabolismo social y los conflictos socio-ambientales en la India

Este artículo exlica los métodos seguidos para calcular los flujos de energía y de materiales en cualquier economía, y da los resultados (de Singh y otros, 2012) de los cálculos de Flujos de Materiales en la India desde 1961 hasta 2008. Incorporando investigaciones realizadas en el proyecto EJOLT, mostramos la conexión entre el cambiante metabolismo social y los conflictos de distribución ecológica, con las protestas en Odisha sobre la minería de bauxita, los conflictos sobre la "minería" de arena en varios lugares de la India, los debates sobre la gestión de la basura en Delhi, y el desguace de barcos en Alang, Gujarat. Nuestro objetivo es combinar en un solo marco la historia del metabolismo social y la historia de los conflictos socio-ambientales y los distintos lenguajes de valoración usados por los actores sociales de tales conflictos.

PALABRAS CLAVE: crecimiento económico; flujos de materiales; mineria de bauxita; mineria de arena; tratamiento de basura; desguace de barcos; movimientos ambientalistas

\section{The Standard Of Living}

The industrial economy works in practice by shifting costs to poor people, to future generations, and to other species. Could an industrial economy work otherwise? The impacts occur at various temporal and geographical scales. They arise because of the 
increased social metabolism, and this article shall show what the main trends in India are.

Sometimes, environmental liabilities appear in the public scene when there are complaints or when there are sudden accidents as in Bhopal in 1984 or Fukushima in 2011 and so many other cases. But here we shall look at those other scenarios that very rarely make the headlines. Shrivastava's and Kothari's brilliant book of 2012, Churning the Earth: the Making of Global India is written in the spirit of Karl Polanyi's Great Transformation, and also draws on the critique of uniform development brought forward since the 1980s by Ashish Nandy, Shiv Visvanathan, Arturo Escobar, Gustavo Esteva, Wolfgang Sachs (1991) and Norgaard (1994). ${ }^{1}$

Shrivastava and Kothari also draw on ecological economists such as K.W. Kapp and Herman Daly, and they criticize Amartya Sen's notion of "development as freedom" (Sen, 1999). Development is not only growth of income per capita and the movement of low productivity farmers into higher productivity occupations, together with industrialization and urbanization. Sen's canvass is broader, and can be summarized in the caption of "capabilities". Development should really mean to acquire the material circumstances and the mental and social abilities to choose as much as possible your own path in life. One can agree with all this but there is still in Amartya Sen a positive view of economic development in contrast to the critics of development quoted above. From the current Indian experience, Shrisvastava and Kothari assert that "development as freedom" falls short of accounting for disappearing natural environments and human cultures, and they ask why "even as sophisticated a writer as Amartya Sen... omits any discussion on the loss of land and livelihood, human community and culture that is invariably involved in the displacement induced by development". In Sen's writings, the natural environment has been seen, if at all, as amenities to be enjoyed once you are well off although in fact, using Sen's own conceptual framework, it could be claimed that what development achieves is the loss of traditional "entitlements" to products and services formerly available outside the market. This is taken up again below in the section on "the GDP of the poor".

\footnotetext{
${ }^{1}$ Wolfgang Sachs edited a collection of these authors' writings (Sachs, 1991) including also Serge Latouche and Vandana Shiva. They are seen in retrospect as "post-development" thinkers. There is a straight line from their critique of uniform development to today's notion of Buen Vivir in the constitutions of Bolivia and Ecuador.
} 
There is still a persistent trend among economists to see the environment as a luxury good and to consider that the poor are "too poor to be green" (Martinez-Alier, 1995 \& Temper \& Martinez-Alier, 2007). This view is vigorously opposed by Shrivastava and Khotari whose book is dedicated to the many movements for ecological and social justice taking place today in India and elsewhere.

In British historiography, there was a debate on whether the "standard of living" for the common people increased between 1760 and 1850, and on what the "standard of living" meant. In India, a country that at present is compressing into a short time socioeconomic historical periods that could be represented in the West by Charles Dickens, Henry Ford and Bill Gates, there could be a similar debate. Moreover, sensitivity to environmental values and the diversity of languages and cultures has increased since E.P. Thompson and Eric Hobsbawm have argued for a more "pessimistic" interpretation of British society.

The British "standard of living" debate is relevant to today's India. and these historic issues are not only defined by the enclosures and the application of the "Poor Laws", but also by the rate of increase in real wages of labourers and industrial workers. Quality of life had deteriorated (in terms incommensurate with money wages) because of overcrowded urban housing conditions, pollution, loss of access to land and loss of status of independent skilled workers. In due course, the condition of the English working class improved. This improvement was due to the increasingly efficient power of coal to move the machines of the "thermo-industrial" revolution (Grinevald, 1976) and to the making of markets for the textile industry all over the world, including India. It was also due to the slowly increasing union power of the new working class and the political power of Britain to exploit other territories, both in its colonies, and in the southern United States which, until the 1860 s, exported to Britain cheap slave labourpower and cheap soil services transformed into cotton. The "ghost acres" and slave labour-time in sugar production in the Caribbean also helped (Hornborg, $1998 \& 2007$ ).

Although they tried, the British were far from being able to literally strip the world bare like locusts because there were too few of them (about 27 million by 1870), many were poor, and also because coal was extracted from the island itself. In 1870 (when Charles 
Dickens died) coal extraction in Britain was to the tune of three to four tons per person, a figure that rose per capita until $1914 .^{2}$

Poverty itself had been created by enclosures and dispossession. It decreased in Britain after the first decades of the thermo-industrial revolution but there were many losses unaccounted for. Then, something unexpected happened internationally that should have dampened the positive views on the thermo-industrial revolution. In 1896 Svante Arrhenius published the first articles showing that temperatures would increase because of increased carbon dioxide concentration in the atmosphere by burning coal. Nevertheless, climate change was not a spanner thrown into doctrines of economic growth until 1985, ninety years later, with the creation of the IPCC. The Intergovernmenal Panel on Climate Change has been chaired since 2002 by an Indian, Dr R.K. Pachauri. The IPCC copes with the impossible task of making climate change one main political issue in India and the world.

There was early awareness that the economy was increasingly relying on non-renewable sources of energy. From Jevons in 1865 to Patrick Geddes from the 1880 s to the 1920 s, and Frederick Soddy in the 1910s and 1920s, it was repeatedly pointed out that economic growth was based on fossil energy stocks which were being burnt and irreversibly dissipated. Later, in the late 1940s, calculations of "peak oil" began to appear, and in the 1970s estimates of a decreasing EROI in agriculture and in the commercial energy sector (Pimentel, et al., 1973; Hall et al., 1986; Martinez-Alier, 1987 \& 2011)

Energy cannot be recycled, therefore even an economy that would not grow but that would use large amounts of fossil fuels, would need "fresh" supplies coming from the commodity frontiers. The same applies to materials, which in practice are recycled only to some extent (like copper, aluminium, steel or paper). Water is recycled in nature by sun energy but we use groundwater and sometimes also surface water quicker that it is replenished. When the economy grows, the search for water and other materials and energy sources is of course even greater.

\footnotetext{
${ }^{2}$ In India coal extraction is still only about $0.5 \mathrm{t} / \mathrm{cap} / \mathrm{yr}$, mainly for electricity production (a process somewhat more efficient than 1870 steam engines). 


\section{The GDP of the Poor}

When economic historians reconstruct GDP series, they would have to balance gains (in monetary and non monetary terms) with losses. A notion developed in India that points to such unaccounted losses is denominated the "GDP of the poor", and was popularized by the reports published in 2008 and 2010 of The Economics of Ecosystems and Biodivesity (TEEB). Authors Haripriya Gundimeda, Pushpam Kumar and Pavan Sukhdev in the first TEEB report "found that the most significant beneficiaries of forest biodiversity and ecosystem services are the poor, and the predominant economic impact of a loss or denial of these inputs is to the income security and well-being of the poor". Here "economic" and "income" are not or should not be meant in a chrematistic sense.

Assume a woman making a living by collecting shells in a mangrove forest with a husband who sustainably produces charcoal for the family and for the local market. Assume that a local shrimp farming corporation or an urban developer encloses the mangrove forest and destroys it (legally or illegally). The loss in the standard of living because of displacement, the increased fear because of threats of security guards, lack of access to food and domestic energy, are not well measured in money terms. That family is likely to lack money to compensate for the losses through buying alternative accommodation and other sources of livelihood. The notion of equivalent compensation itself is in question. Moreover, the surrounding populations are now in danger because they lack protection against storms or tsunamis and, furthermore, there has also been a loss of biodiversity in itself, beyond products or services for humans.

Assume (as in India which is driven by an increased extraction of materials), that a poor rural woman working at home and also outside the home for subsistence or for wages, finds that that the water in the river or the well is now polluted because of mining nearby. This water which was once free (providing if social institutions of caste allowed access to it) is now polluted, and this woman is unlikely to have money, even if she gets 
a NREGA ${ }^{3}$ wage to buy the plastic bottles for the water need for the family. If she buys water she cannot buy food or wood or clothes.

When people see their access to nature's products or services destroyed by deforestation, mining, tree plantations, dams or transport infrastructures, they often complain. They might ask for compensation (to "internalize the externalities") or, very likely, they will eschew chrematistic accounting and appeal instead to a language of rights.

\section{Ecological Distribution Conflicts and the Defence of the Commons}

The increased use of fossil fuels and minerals, the human appropriation of the available biomass, the diversion of water to industrial use etc., all bring about an increase in conflicts related to the access to environmental products and services and on the distribution of the burdens of pollution. This does not imply that poor people are always on the side of conservation, which would be patently untrue. However, in many conflicts born out of resource extraction, transport or pollution, the local poor people (indigenous or not) are often on the side of conservation not so much because they are explicitly environmentalists but because of their livelihood needs and (often) their cultural values (Guha \& Martinez-Alier, 1997; Martinez-Alier, 2005).

Therefore, there are movements of environmental justice or an environmentalism of the poor and the indigenous often appealing to non-monetary values such as livelihood, territorial rights or sacredness of the land or the rivers. These movements combine livelihood, social, economic and environmental issues. They set their "moral economy" in opposition to the logic of extraction of oil, minerals, wood or agrofuels at the "commodity frontiers", and thus defend biodiversity and their own livelihood. In many instances they draw on a sense of "place" and local identity (indigenous rights and values) but they also could connect easily with the politics of the Left. However, the traditional left in southern countries (as in West Bengal in 2007) still tends to see environmentalism as a "luxury of the rich". The same applies to the nationalist-popular movements in Latin America. However, there is currently a change in some circles of

\footnotetext{
${ }^{3}$ The Mahatma Gandhi National Rural Employment Guarantee Act guarantees a hundred days of wageemployment in a financial year to a rural household whose adult members volunteer to do unskilled manual work. 
the intellectual and political left in Latin America with authors such as Alberto Acosta, Eduardo Gudynas and Maristella Svampa who draw inspiration from the critics of development of the 1980s and from political ecology.

India's socio-environmental conflicts have their peculiarities. There are not so many foreign corporations as in Latin America, Indonesia and Africa (from Canada, China, the United States, Australia, Europe) engaging in open cast mining or fossil fuel extraction. There are no foreign land grabs in rural areas of India, on the contrary there are some Indian land grabs outside India. There are no foreign-owned large plantations of oil palms or eucalyptus. In India there are many conflicts related to the mining of coal and lignite, bauxite, iron ore (usually by domestic corporations, public or private). Furthermore, there are conflicts involving illegal sand and gravel extraction, which do not happen so often in other countries. There are also biomass conflicts (deforestation, tree plantations), conflicts regarding water use (dams, excessive consumption of underground water, pollution by mining and by industry) which are common to other countries. There are also renewed conflicts concerning the uncertain risks from nuclear electricity, as in Maharashtra (Ranatgiri) where there is opposition to the French Jaitapur grandiose nuclear projects. In Tamil Nadu the Russian-built Kudankulam power plant of Russian design has caused much social unrest, and in December 2012 "fishermen from the coastal villages set out into the sea in more than 100 boats towards the Kudankulam nuclear power plant while women and children stayed back at the protest site in front of St Lourdes Church in Idinthakarai, the epicenter of the 400-daylong protest". 4 At the other extreme of the "commodity chain", there have been persistent conflicts regarding uranium mining in Jharkhand.

Until 2011, it was foreseen that in Haripur, West Bengal, six Russian-built nuclear power plants were to be installed in the region. ${ }^{5}$ This was to be a second nuclear park, after Kudankulam. Haripur was set to be operational once all the six reactors at Kudankulam became operational. However, this met with opposition, and after peasant opposition had prevented in 2007 the setting up of SEZ (special economic zones) at Nandigran and Singhur (for the chemical industry and for a Tata car factory), the

\footnotetext{
${ }^{4}$ Times of India, 11 Dec. 2012

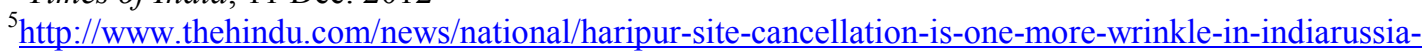
ties/article4026380.ece
} 
Communist Party government of West Bengal, which also favoured Haripur, was defeated in the elections. Its general secretary, Prakash Karat, complained in 2007 against "the modern-day Narodniks who claim to champion the cause of the peasantry" while neglecting the historic task of industrialization. He mentioned "the likes of Medha Patkar" among the Narodniks. ${ }^{6}$

Interestingly, one main spokesman for the new party AAP in India, Yogendra Yadav, has said: "... the most creative energy in our public life has not come from within politics proper but from outside politics - from people's movements on issues such as displacement, Dalits, farmers, women, right to food, right to information and above all, jal, jungle, zameen (water, forests, land). The difficulty is that this energy did not have a political expression, hope, and a political vehicle. In my dream script, the AAP is the natural political hope for these energies". ${ }^{7}$

Anywhere one goes in India, one can find small civil society organizations (Gandhian and, in an Indian sense, Narodnik) both documenting and becoming actively involved in conflicts on land-grabbing, water grabbing and expoliation of other natural resources. One such group in Allahabad claims that defense of the people's "communitarian ownership of natural resources is the underlying idea behind the mass upsurge, assertion and activism" in states like Jharkhand and Chhatisgargh against coal mining, in Uttarakhand and other Himalayan states against dams, in Tamil Nadu, Maharashtra, Haryana against nuclear energy threats. Thus, in Jharkhand, in the Karapura valley of Hazaribagh, "indigenous and agrarian populations of 205 villages have not allowed the entry of 35 corporations to start mining of coal and build large thermal power stations", while in Haryana "rural people in and around the village of Gorakhpur of Fatehabad district are opposing the proposed nuclear plant there. They have been sitting in a continuous dharna since July 20, 2010. Three persons have died while sitting dharna" ${ }^{8}$

\footnotetext{
${ }^{6}$ http://pd.cpim.org/2007/0128/01282007 prakash.htm

72 Dec. 2013, http://www.thehindu.com/todays-paper/tp-opinion/tapping-the-transformative-energy/article5495629.ece 8 Nai Azadi, monthly journal of Azadi Bachao Andolan, Oct-Dec 2012, special issue in memory of Prof. Banwari Lal Sharma, issued by the Swaraj Vidyapith in Allahabad. Dharna is the practice of demanding redress for an offense by sitting down and fasting at a public place or at the doorstep of the offender or debtor.
} 
The primary causes of such movements of resistance are the increase in the social metabolism and the defence of communitarian livelihoods against resource extraction. Meanwhile, there are also new urban waste disposal conflicts. The questions we must now ask ourselves are: which of these types of conflicts already existed in 1947, and which ones are new? Furthermore, one must ask oneself what are the current trends? Are there historical studies of political ecology following the pioneering work of the 1980s and 1990s by Ramachandra Guha, Rohan D'Souza and other authors on forests and water management conflicts since colonial times? ${ }^{9}$

\section{Methods for the Study of Social Metabolism}

Economies may be described in terms of economic indicators such as growth of GDP, savings ratio, budget deficit as percentage of GDP, current account balance in the external sector, and so forth. Social factors may be taken into account, as in the Human Development Index which nevertheless correlates closely with GDP per capita leaving aside (as Shrivastava and Kothari emphasize) environmental and cultural loses.

The economy may also be described in terms of physical indicators. Economic, social, and physical indicators are non-equivalent descriptions. For example: a particular economy may provide 260 GJ (gigajoules) of energy per person/year, its HANPP (human appropriation of net primary production of biomass) is $35 \%$, material flow amounts to 16 tons per person/year of which fossil fuels account for 5 tons. Of the material flows, 5 tons are imported, 1 ton is exported. Income per capita is 34,000 US\$, and therefore it ranks 10th in the HDI (human development index).

To take another example, we have an economy that provides only $35 \mathrm{GJ}$ person/year, its materials flow amounts to only 5 tons person/year, its HANPP is 65\% (a heavily populated country, relying on biomass, with little external trade). Foreign trade is less than 0.3 ton per capita/year of exports or imports. Income per capita is 3,000 US\$ (at purchasing power parity) and, therefore, it ranks 127th in the HDI. Different regions and

\footnotetext{
${ }^{9}$ There is an overview of India's environmental history in Rangajaran and Sivaramakrishnan (2012) . This is a formidable collection but it does not trace changes in the growing human use of energy, materials and water, and the resulting ecological distribution conflicts in rural and urban areas. There is more research on social metabolic trends (particularly energy, including biomass) and on environmental conflicts in D'Souza, 2012.
} 
different classes of people in such countries could be classified by their metabolic profiles.

MEFA -materials and energy flows accounting- is a set of methods for describing and analysing socio-economic metabolism. It examines economies as systems that reproduce themselves not only socially and culturally, but also physically through a continuous exchange of energy and matter with their natural environments and with other socio-economic systems. Material flow accounts are published at national level by Eurostat and now also UNEP, drawing on methodologies established by research groups such as the one led by Marina Fischer-Kowalski in Vienna over the last twenty years. We suggest that material flow accounting is also needed at regional (state) level, and we wonder whether this is being done or will be done officially in India. All-India's accounts show levels of domestic extraction per capita and trends very different from those that would be shown by individual states, some of which have very large Physical Trade Deficits as they perform the role of suppliers of cheap materials.

In the Material Flows we calculate first the Domestic Extraction (in tons per year) divided into Biomass, Minerals for Building Materials, Mineral Ores for Metals, and Fossil Fuels. They show different levels and trends in different countries. The Domestic Extraction is denoted as DE. The DMC (Domestic Material Consumption) is equal to Domestic Extraction plus Imports minus Exports. ${ }^{10}$ Physical imports and physical exports measure are all imported or exported commodities in tonnes. Physical trade balance (PTB) equals physical imports minus physical exports. So countries like Brazil or Russia (among the BRICs) have large Physical Trade Deficits, but not India as a whole. Such accounts (including carbon or energy "rucksacks", "virtual" water and "embodied HANPP") are relevant for historical and current debates on ecologically unequal exchange and the ecological debt.

Energy flow accounting (EFA) is an integral part of the analysis of social metabolism. Primary and final energy delivered are usually classified in the statistics according to source. Such energy flows (including hydro-electricity) are also unequally distributed, and in India they are creating not only coal mining conflicts and the new nuclear

${ }^{10}$ The Material Flows of India have been calculated in S.J. Singh, et al, 2012. 60 
conflicts but also conflicts in the Himalaya and in the North East on hydroelectricity. Notice that energy accounts are separate from the Material Flows. The idea of linking economic history to the use of energy goes back to Wilhelm Ostwald, and later to Leslie White and other authors but it was only in the 1980s when several histories of the use of energy in the economy were published. The most interesting EFA indicator is that of Energy Return on Energy Input (EROI).

The question arises whether economic growth will be slowed down around the world as and if we enter a period of decreasing EROI. Are industrial late comers damaged by this? An economic-ecological history would establish the changes in the EROIs in a country such as India over the coming years. This would register a remarkable improvement as biomass energy is substituted or supplemented by fossil fuels and would later in turn, indicate perhaps a decline due to the fact that obtaining energy while going down the Hubbert curve (after peak oil) requires (it seems) increasing amounts of energy.

\section{The HANPP}

The HANPP (human appropriation of net primary production of biomass) is calculated in three steps. First, the potential net primary production (in the natural ecosystems of a given region or country), NPP (net primary production), is calculated. Then, the actual NPP (normally, less than potential NPP, because of agricultural simplification and soil sealing) is calculated. The part of actual NPP used by humans and associate beings (cattle, etc.) relative to potential NPP is the HANPP, and this is meant to be an index of the pressure on the biodiversity (due to the higher the HANPP the less biomass is available for "wild" species). So, an increasing HANPP is an indicator of increasing pressure on biodiversity. This data would be relevant to undertake a history of India's conservation areas and threats to its wildlife.

In India, due to high population density and land conversion, and due also to a relatively high use of biomass per capita (which would still be larger if the Indian population ate more meat), the Human Appropriation of Net Primary Production is very high (as it is also in Bangladesh). S. J. Singh et al (2012) put it at $73 \%$ compared to about $40 \%$ in the EU (with comparable population densities), and only 24\% in Japan (a country that 
imports much biomass). Therefore, the higher the HANPP the stronger the pressure on biodiversity. We can also ask the question of which social group actually benefits from the HANPP as in the scenario when a commercial tree plantation is planted in a former forest used sparsely by Adivasi groups.

\section{India's Social Metabolism}

Following the example set by Japan for the last twenty years, economic growth has stopped in many rich countries since 2008 (less by design than by the economic crisis), while in the BRICs but also Peru, Indonesia, Colombia, Turkey and many other countries there has been growth after 2008. Poverty in terms of income per capita is declining in all such countries, including India.

This growth is achieved at great environmental and social costs. There is land grabbing and enclosures, peasants are squeezed out of the land, tribals in India and elsewhere are being displaced because they happen to live at the "commodity frontiers", and the consequence is that biodiversity is being rapidly lost.

This is the background to the study of India's Material Flows in 2012. India per capita still consumes less fossil fuels, less building materials, and less mineral ores than many other countries. In the $1960 \mathrm{~s}$, about three quarters of the total material consumption consisted of biomass while construction materials were second in importance. Fossil fuels and industrial minerals and ores were insignificant in relation to the total flows. In the course of the approximately 50 years of study, this relationship has changed in quantity and composition. The use of biomass has doubled while fossil fuel consumption multiplied by a factor of 12.2, industrial minerals and ores by a factor of 8.6 , and construction materials by a factor of 9.1

Until the 1980s the population grew at a slightly faster pace than material throughput. Throughout the 1960s and 1970s, material use remained at a low and slowly declining level of less than $3 \mathrm{t} / \mathrm{cap} / \mathrm{yr}$. Only since the early 1980s (ten years before Dr Manmohan Singh became Finance Minister in 1991) a sustained growth in per capita material consumption set in, growing by over $60 \%$ to $4.3 \mathrm{t} / \mathrm{cap} / \mathrm{yr}$, and accelerating in the period since 2004. Taking into account further growth from 2008 to 2012, India is probably at a level of $5 \mathrm{t} / \mathrm{cap} / \mathrm{yr}$. In comparison, per capita material consumption in EU countries is 62 
about 15 tons per person/year. (Notice moreover that in the EU imports are very significant, and they exceed exports in tons by a factor of 4).

As regards the material intensity (or its reverse, resource productivity), India's GDP (in constant 2000 USD) increased by a factor of 12.4 between 1961 and 2008. The monetary economy grew faster than the physical economy. The material intensity of the Indian economy, measured as the ratio of DMC (domestic material consumption) per GDP, declined by $69 \%$, from almost $20 \mathrm{~kg}$ of DMC per \$ GDP to only $6 \mathrm{~kg}$ per $\$$. This decline can be attributed to the slow growth of biomass consumption that only doubled. In contrast, the use of minerals and fossil fuels grew at about the same pace as GDP. In Singh et al (2012) we wrote that, in general, construction minerals are abundant and scarcity (and extraction conflicts) are usually only regional phenomena. But almost all regions of India suffer from the phenomenon of "sand mafias".

As regards trade, India has no Physical Trade Deficit, and this fact has become bothersome for theorists of Ecologically Unequal Trade. In the case of India, unequal trade has to be analysed at state level. For instance, as we shall see, Odisha is a large net exporter, and its exports cause locally large environmental and social damages. Could Odisha tax exports substantially for its own benefit?

The trends in total and per capita material domestic consumption in India (extraction plus imports minus exports), on material intensity, and on physical trade are summarized in Fig. 1. 
Fig. 1 Material flows accounts of India 1961-2008 (source, Singh et al 2012, op. cit).

a) Total domestic material consumption (DMC)

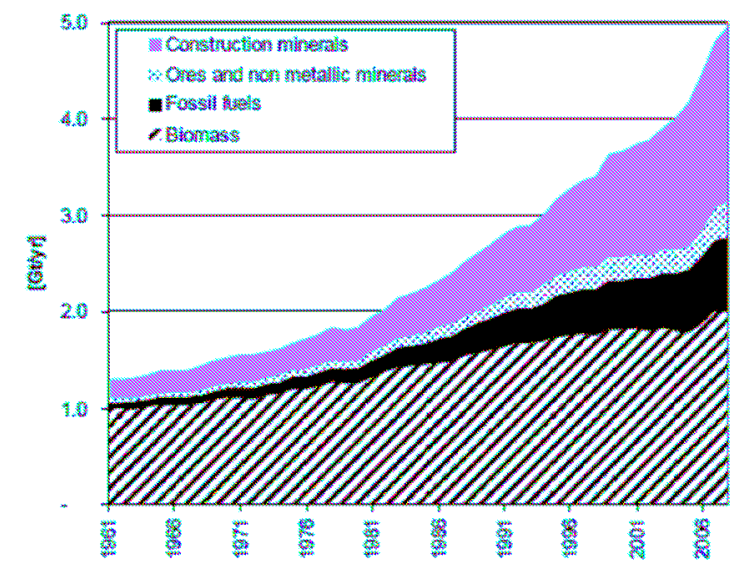

b) Domestic material consumption per capita

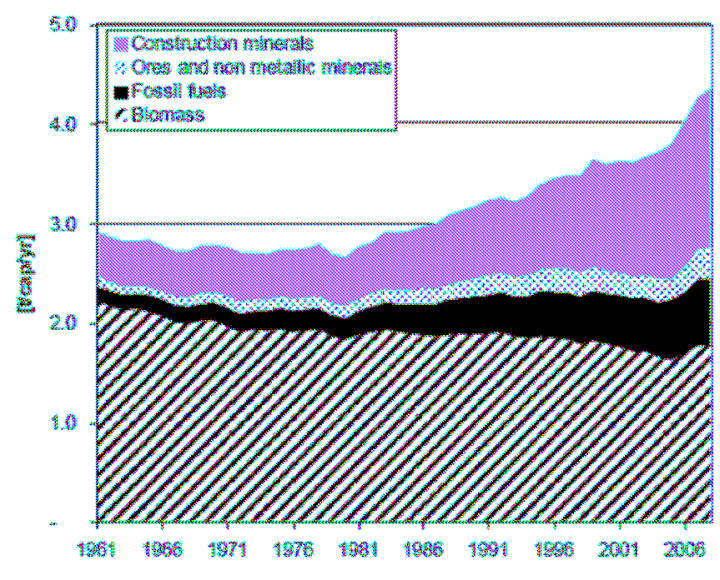

c) Trade flows as compared to domestic extraction

d) Material intensity of the Indian economy (DE)
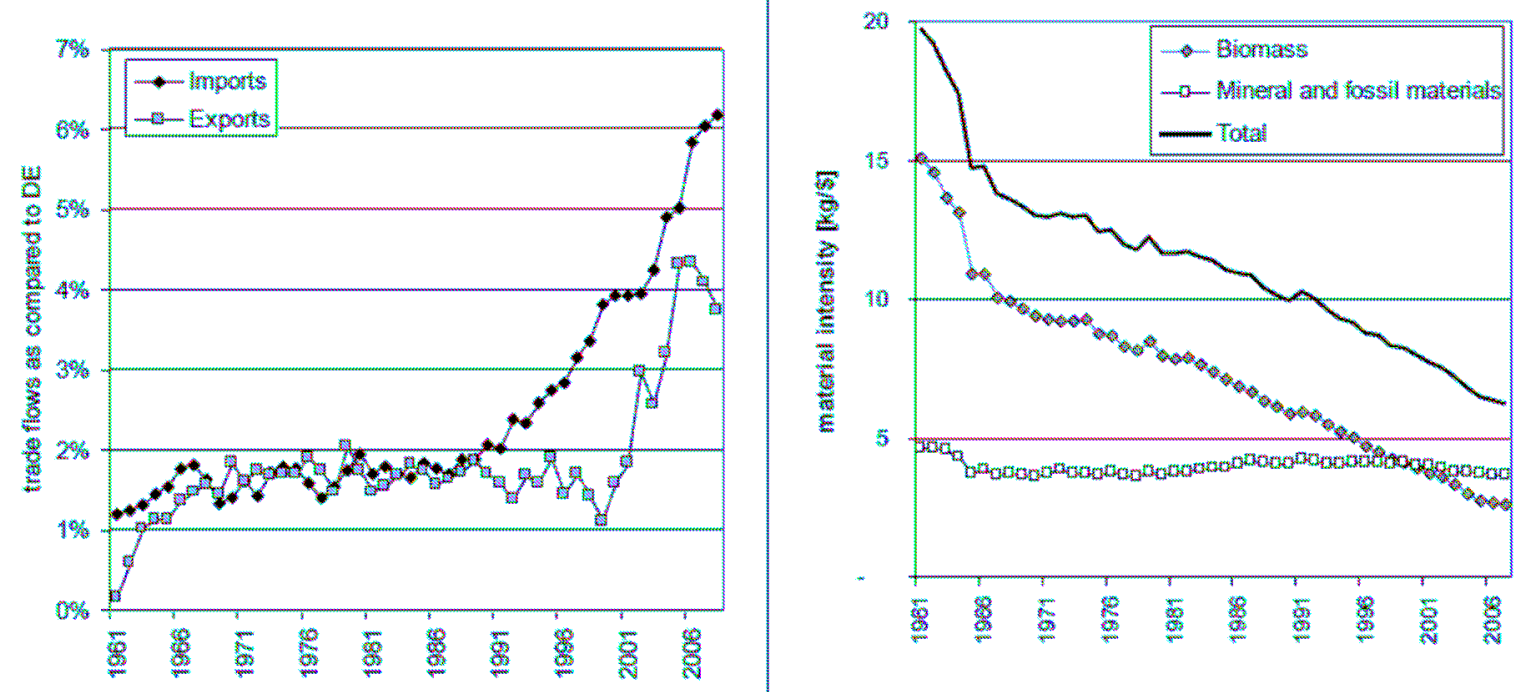
Table 1 shows again the Domestic Material Consumption (Domestic Extraction + Imports - Exports) per capita from 1961 to 2008, excluding the Biomass, comparing with growth of GDP and population.

\begin{tabular}{|l|l|l|l|l|l|}
\hline & 1961 & 1980 & 2008 & $\begin{array}{l}1961- \\
1980\end{array}$ & $\begin{array}{l}1980- \\
2008\end{array}$ \\
\hline $\begin{array}{l}\text { GDP [billion USD at const. } \\
\text { 2000] }\end{array}$ & 66 & 156 & 812 & $3.5 \%$ & $6.0 \%$ \\
\hline Population [million) & 444 & 687 & 1140 & $2.3 \%$ & $1.8 \%$ \\
\hline $\begin{array}{l}\text { Fossil energy carriers [DMC } \\
\text { t/cap/yr] }\end{array}$ & 0.1 & 0.2 & 0.6 & $4.7 \%$ & $6.0 \%$ \\
\hline $\begin{array}{l}\text { Ores and industrial minerals } \\
\text { [DMC t/cap/yr] }\end{array}$ & 0.1 & 0.1 & 0.3 & $3.4 \%$ & $5.6 \%$ \\
\hline $\begin{array}{l}\text { Construction minerals [DMC } \\
\text { t/cap/yr] }\end{array}$ & 0.4 & 0.5 & 1.6 & $2.0 \%$ & $6.2 \%$ \\
\hline
\end{tabular}

Table 1: DMC [t/cap/yr] of India for the three main groups of mineral and fossil materials and their average annual growth rates (\%) in comparison to population and GDP. Source: Singh et al (2012)

\section{Regional Variations in Social Metabolism and Resource Extraction Conflicts: the Case of Odisha}

In this section (inspired by Felix Padel and Samarendra Das over the years) we shall account for the historical novelty in the very long recorded history of Odisha: the clashes due to the plans for mineral extraction, as in Maikanch, or due to the cases of industrial land grabbing, as in Kalinganar (Padel \& Das, 2010).

The mining and quarrying sector has been the fastest growing sector in Odisha at above $10 \%$ per annum growth since $1980-81$ to $2008-09$ and beyond. Yet at the same time, virtually the whole of Odisha, including Kashipur in Rayagada, Lanjigarh in Kalahandi, Lower Suktel area in Balangir, Kotagarh in Phulbani, the mining-industrial belt in Jharsuguda, Kalinganagar and Rourkela, has turned into a battleground over the issue of development and displacement. The issue at hand in these conflicts is sometimes demanding better compensation packages, but often communities are raising serious objections to the notion of development itself that is being promoted, and they champion a different system of values plus an alternative vision of development to that advocated by the state. The Niyamgiri-Lanjigarh case, as well as the struggle over the 
investments of the Korean steel company POSCO, have become emblematic of these clashes which are also experienced in neighbouring states. ${ }^{11}$

While other growing economies such as Brazil, Argentina, Russia and South Africa have large physical trade deficits in relation to the size of their economies, India's exports and imports (in tonnes) are relatively small in comparison to the physical size of her economy (Fig. 1). However, within the subcontinent, there are resource-rich regions with very large net material exports to foreign countries and to the rest of India. As such, looking at material flows only at a national level obscures large variations between per capita (and per hectare) material extraction between states. Particularly in the eastern part of the country in states such as Jharkhand, Chhattisgarh and Odisha, the ecological distribution conflicts associated with the growing social metabolism can be most clearly evidenced and, furthermore, if we study energy flows we can understand the resistance to hydro-electric developments in other areas. It is always the same story: from increased social metabolism in terms of materials and energy comes socioenvironmental conflicts.

Odisha is the $9^{\text {th }}$ largest state by area in India and the $11^{\text {th }}$ largest by population, and the region holds many minerals. However, despite (or because of) increasing exports of this wealth to other regions, it remains one of the poorest states in India with a sum total of $40 \%$ of its inhabitants below poverty line (Economic Survey, Government of Orissa, 2003-04 and 2008-09). Recent years have seen unprecedented levels of investment from both domestic and international companies hoping to profit from this mineral bounty. In 2009, Odisha was the Indian state with the $2^{\text {nd }}$ most Foreign Direct Investment (FDI), after industrial Gujarat.

In states like Odisha, the incidence of mining is much larger than in the country as a whole. Iron ores, coal, bauxite together with other minerals extracted reach in Odisha 4.7 tons per capita per year (Table 2), with rapid increase since 1980. We have observed that the incidence of conflicts depends on the growth in extraction within a region, however there does not exist a rule as to the amount of extraction in tons in proportion to the number and intensity of conflicts. The type of mineral and the rate of growth are

\footnotetext{
${ }^{11}$ And also in distant Goa and Karnataka where there have been bans imposed by the Supreme Court of iron mining and exports, because of corruption in mining permits and because of environmental damage. http://www.ejolt.org/2012/12/the-ban-on-iron-mining-in-goa/ 
relevant together with other variables such as population densities, water scarcities, indigenous presence, and local political activism.

Table 2: Extraction of important minerals in Odisha, 1960 - 2000

\begin{tabular}{|l|l|l|l|l|l|}
\hline Year & Iron ore & Coal & Bauxite & All minerals & $\begin{array}{l}\text { Tonnes per } \\
\text { capita }\end{array}$ \\
\hline $\begin{array}{l}{[\text { million }} \\
\text { tons/yr }]\end{array}$ & $\begin{array}{l}{[\text { million }} \\
\text { tons/yr }]\end{array}$ & $\begin{array}{l}{[\text { million }} \\
\text { tons/yr }]\end{array}$ & $\begin{array}{l}{[\text { million }} \\
\text { tons/yr }]\end{array}$ & \\
\hline 1960 & 3.5 & 0.9 & 0 & 8.9 & 0.5 \\
\hline 1970 & nd & nd & 0 & 12.3 & 0.6 \\
\hline 1980 & 6.6 & 3 & 0 & 14.6 & 0.6 \\
\hline $1988-89$ & 7.3 & nd & nd & 31 & 1.0 \\
\hline $1995-96$ & 9.3 & 32.6 & 2.4 & 51.3 & 1.5 \\
\hline 2000 & 14.3 & 47.8 & 2.9 & 87.3 & 2.4 \\
\hline $2005-06$ & 48.0 & 70.5 & 4.9 & 138.7 & 3.6 \\
\hline $2008-09$ & 77.1 & 97.7 & 4.7 & 189.0 & 4.7 \\
\hline
\end{tabular}

Source: Statistical Abstracts of Orissa 1961, 1969, 1979 \& Economic Survey 2003\&2006 and Directorate of Mines, Government of Orissa:

http://www.orissaminerals.gov.in/Mines/MineralProduction.aspx?GL=ming\&PL=3

Odisha holds one-third of the country's iron ore reserves, a quarter of its coal, half its bauxite and more than $90 \%$ of its nickel and chromite. The state, under the firm government of Naveen Patnaik who has been relected several times, has attracted large investment proposals from Tata, Jindal, Posco, Arcelor Mittal and Vedanta, while some large investment projects include the building of new harbours. Conversely, there exists many problems over land acquisition, accusations of corruption, and violations of environmental regulations, and this has brought about an increase in the Naxalite presence within the state. ${ }^{12}$ Nonetheless, while the increase in mineral extraction is undeniable, this process will most probably be slowed down in 2013 due to two factors; Odisha (as Karnataka and Goa) is undergoing a review of illegal iron ore leases, and the Vedanta fiasco in Lanjigarh. ${ }^{13}$

\footnotetext{
${ }^{12}$ The Naxalites are various militant groups of Maoist origin that predate the economic boom.

13 “Games Vadanta Plays", 2012.
} 
Compare with Table 3 for the whole country, which shows rapid growth and then stagnation (for metallic minerals) due sometimes to (as acknowledged by the Ministry of Mines' Annual Report of 2011-12) a “temporary discontinuance of mining for want of environmental clearance". ${ }^{14}$

Table 3. Extraction of some key minerals (1000 tons per year).

\begin{tabular}{|l|c|c|c|}
\hline Years & $\mathbf{1 9 9 7 - 9 8}$ & $\mathbf{2 0 0 8 - 0 9}$ & $\mathbf{2 0 1 0 - 1 1}$ \\
\hline Bauxite & 6108 & 15250 & 13172 \\
\hline Coal & 297000 & 493000 & 533000 \\
\hline Iron Ore & 75723 & 225544 & 191522 \\
\hline Chromite & 1515 & 3976 & 3900 \\
\hline
\end{tabular}

Source: Shrivastava and Kothari, 2012: 125 from Ministry and Coal and Mines, Annual Report, 2001-02, Ministry of Mines, Annual Report, 2008-09; last column has been added from Ministry of Mines, Annual Report, 2011-12.

Although they do not yet provide a systematic Political Ecology of resource extraction and waste disposal conflicts in India, linking social metabolic flows to such conflicts, Shrivastava and Khotari (2012, p. 125) eloquently state that the socio-environmental impacts of mining are horrifying and they are far from being randomly distributed. "The blasted limestone and marble hills of the Aravallis and Shivaliks; the cratered iron ore or bauxite plateau of Goa, Madhya Pradesh and Orissa (Odisha); the charred coal landscapes of eastern India; and the radioactive uranium belt in Jharkhand are all witness to the worst that economic "development" can do". The worst affected, they conclude, are possibly the adivasis of central and eastern India.

While Odisha had only two iron and steel plants in 1995, today there are 14 steel plants and four pig-iron plants in the state. Yet this was only the tip of the expansion, with over 43 Memoranda of Understanding (MoUs) to set up steel plants already signed by 2005 (Asher 2009), including a \$12 billion dollar plant that South Korean company POSCO aims to establish near Paradip Port, plans from Arcelor-Mittal to invest in a mega steel plant worth $\$ 10$ billion, and Russian Magnitogorsk Iron and Steel Company (MMK) plans to set up a 10 MT steel plant. The state is also attracting record investment in aluminum, coal-based power plants, and petrochemicals. Proposed investments would see an annual production of 76 million tons of steel, 5 million tons of cement, 4 million tons of aluminum and 25,000 MW of electricity to fuel this production in the coming years (Mishra 2010).

\footnotetext{
${ }^{14}$ http://mines.nic.in/writereaddata\%5CContentlinks\%5C1ed4a15b370646d7be2c6defb2ecf6c9.pdf 68
} 
Examining the relevant material flow data from 1960-2006 (Table 3), Odisha's role in providing itself and the rest of the country with minerals can be seen. In 2008-09, over 4.7 tonnes of minerals (including coal) were mined per capita in Odisha - the equivalent of the per capita consumption of all materials including biomass for an average Indian. The growth of the mining sector was vertiginous from 1995 onwards, when the deregulation of the mining sector allowed increased foreign investment and more statelevel control over mining concessions (Asher 2009).

The need for land acquisition in a wide wave of enclosures to accommodate Special Economic Zones and mines, often forestland, has induced local level conflicts between the state and those slated to be displaced. The population density in Odisha is close to the average for India (approximately 300/ $\mathrm{km} 2$ ) leading to extreme land scarcity in a state where $85 \%$ of the population is rural and almost entirely dependent on agricultural land and forest resources for their livelihoods. From 1950-1995 over 250000 people were displaced in Odisha, half of these adivasi. Of these, only $25 \%$ were ever resettled (Fernandes and Asif 1997).

This establishes a clear link between an increasing social metabolism and resource extraction conflicts. In the Odisha state, hydroelectric dams (at the service of the mining industry), eucalyptus plantations and shrimp farms have proved to be no less controversial than open cast mining. Conflicts include the killing of three young men in Maikanch protesting against the UTKAL Aluminum plant in Kashipur on the 16th of December, 2000; in Kalinganagar, 12 people were shot dead by police in 2006 resisting displacement by the industrial conglomerate TATA. The South Korean multinational POSCO's attempts to acquire land for a steel plant that would displace many people growing crops has led to violent clashes, including a protest in 2006 where 11 persons were injured (Padel and Das 2010). As it is well known in India, this type of violence is different from that of Naxalite (or counter-Naxalite) origin. There is a geographical overlap in some areas between Naxalite violence and resource extraction conflicts, although this is not the case in Odisha at the time that these extraction conflict incidents took place. 


\section{Illegal Sand Mining in India}

From a factsheet for the EJOLT project prepared by the Centre for Studies in Science Policy at JNU and from other sources, we take evidence and interpretations regarding this practice (A.A. Singh et al., 2012) which is not unique to India.

Sand mining refers in India to the extraction of sand and gravel from riverbeds and seashores for construction activities and for minerals such as gold, silver, silicates. Mining sand for silica or for metals in coastal areas (such as ilmenite for titanium) is different from "mining" sand and gravel from river beds or beaches as building materials. What in India are called the "sand mafias" refers to those small contractors serving the building industry. There are cases of violence due to sand mining that all too often make the national news.

The increasing demand for materials for the booming real estate and infrastructure projects together with weak governance and rampant corruption, leads to illegal mining of sand and gravel in the rivers of India. The illegality arises because the practice is forbidden as damaging to the environment. These illegal practices have been reported in Madhya Pradesh, Bihar, Haryana, Karnataka, Goa, Andhra Pradesh, Rajasthan, Chattisgarh, Odisha and West Bengal (12 March 2012, Express News Service), as well as Kerala, Tamil Nadu, Maharastra, Gujarat, Uttar Pradesh, Uttarkhand, which pretty much covers the whole country. The Centre for Science and Environment has published several reports on sand mining. The use of excavators to remove sand causes riverbeds to erode, banks to collapse; it damages infrastructure like bridges and transmission lines, and causes problems in drinking water systems. Uncontrolled, illegal sand mining has caused depletion of groundwater tables and degradation of groundwater quality.

In this respect, we shall briefly present three conflicts as regards sand mining and evidence the social agents involved: an environmentalist, a religious priest, and a highranking police officer.

\section{Awaaz Foundation vs. the Sand Mafia}

Awaaz Foundation is an environmental NGO based in Mumbai working extensively on raising awareness about the vulnerability of the environment through educational projects in different states of India. Ms. Sumaira Abdulali, Founder of Awaaz 
Foundation, was physically assaulted on 17 March 2010 by the son and employees of a local politician, who are part of an extensive politically-controlled sand mafia in Maharashtra (17 March 2010, Times of India). The Awaaz Foundation filed a case at the Bombay High Court through Public Interest Litigation, demanding a ban on sand mining activities along the Konkan coast of Maharashtra. As a result, the Bombay High Court banned mining in the Coastal Regulation Zone (CRZ). Moreover, the court ordered the state government to implement the alternative measures mentioned in the report prepared by the prestigious IIT Mumbai (Indian Institute of Technology), which includes reusing sand from building debris and the use of environmentally sound techniques for sand extraction.

\section{Swami vs. the Uttarakhand State}

In June 2011, Hindu priest Swami Nigamananda Saraswati died after a four-month fast in protest of reckless state-sponsored sand mining and stone crushing on the banks of the Ganga, near Haridwar in Uttarakhand. Millions of pilgrims visit this holy place to dip in the river during Kumbh Mela to wash away their sins. A few days before Swami Nigamanand died, the Uttarakhand government ordered a ban on mining activities in the region which is considered sacred. The ban also followed a directive of the Uttarakhand High Court on 26 May 2011 that expressed concerns over the degradation of the river's ecology and in general the area used for Kumbh celebrations (Shrivastava, 2011).

\section{Narendra Kumar (IPS Officer) vs. the Mining Mafia}

In Madhya Pradesh, Narendra Kumar (Indian Police Service, a high-ranking officer) was brutally crushed to death by a tractor loaded with illegally-mined stones, allegedly by the 'mining mafia' in Morena on 8 March 2012. The Chhatarpur district administration ordered the cancellation of all sand mining contracts in the district after the media outrage over the IPS officer's killing, and a second attack on a sub-divisional magistrate and police officials in Panna. Later, the Madhya Pradesh Chief Minister announced they were handing the murder case of the IPS officer over to the Central Bureau of Investigation (13 March 2012, Times of India).

Finally, we consider a case of the People against the Sand Mafia in Tamil Nadu which occurred over ten years ago. The Cauvery River has been seriously impacted by 
indiscriminate sand mining. The groundwater table has been depleted, rendering the water scarce. Decrease in soil fertility has led to a sharp decline in agricultural productivity, forcing farmers to sell off their lands and allowing miners to dredge the precious sand lying beneath their fields. People who realised that their very livelihood was at stake due to mining took to the streets at the call of AREDS (Association for Rural Education and Development) on several occasions. Since 1991, AREDS, together with the local people, women's organisations and activists, organized several road blockades. AREDS also filed a case through Public Interest Litigation (5762/90) to the Madras High Court in 1990. As a result, mining was banned in the Cauvery River by the High Court on 25 January 1999.

In comparison with past decades, the rapid economic growth that India is currently experiencing, coupled with the drive to industrialise, has significantly increased the demand for materials, including sand. Legal sand mining, in line with existing regulations, was not enough to meet the demand generated by the booming real estate and infrastructure projects and, as a result, riverbed and seashore ecosystems are being severely impacted due to sand mining.

\section{Delhi Waste Wars: from Cradle to Grave}

The industrial capitalist system prospers not only by appropriating as cheaply as possible energy and material resources (in a process of accumulation of profits and capital by dispossession, as David Harvey calls it) but it also needs to dispose of waste as cheaply as possible. Waste disposal conflicts have come to the fore due to climate change and this has propelled movements for Climate Justice. There are also injustices related to the appropriation of water and the environmental services that water brings, and this has also motivated movements which have been identified internationally as movements for Hydric Justice.

There are also problems with urban solid waste disposal. The connection to climate change comes through the methane escaping from non-recycled organic waste going to dumps. There are schemes to collect and burn the methane (a powerful greenhouse gas), which are translated into "carbon equivalent credits". In common with so many other cities in the world, Delhi and other cities of India are producing more and more solid 
waste, and have policy debates and social disputes on how to manage this waste. Research by Federico Demaria and colleagues looks at the customary "property rights" that recyclers have on the waste. There are unequally distributed advantages and disadvantages in changing from a system of informal recycling by poor people to a formal system of collecting waste and then burning most of this waste in incinerators.

Authorities in Delhi proclaim that waste management is in a state of crisis. They say that waste is commonly dumped in the open illegally and the existing landfills are over capacity. This narrative portrays the crisis as a failure of management and, furthermore, begs the questions of: what should be done about this crisis, and who absorbs both the costs and the benefits of this change in waste management which has been motivated by the increase in the social metabolism in such a large city?

A modern waste management system, based on subsidizing and supporting the recyclers' unions (as has been set up in Porto Alegre in Brazil and other cities) could consist in separating organic waste from the other waste, and then composting it for fertilizer, while the rest of the waste would be separated (even more than at present by "traditional" recycling) into glass, paper, plastics, to be used as raw materials again. This should be done in hygienic conditions. Such alternatives are being tried in other places. In Pune, for example, waste workers have organised themselves into a union, the Kagad Kach Patra Kashtakari Panchayat (KKPKP) (6,000 members), that has promoted a waste management cooperative, the Solid Waste Collection and Handling (SWaCHCoop) authorised by the Pune Municipal Corporation to provide door-to-door collection.

Instead, what is proposed in Delhi is something unprecedented in the long history of the city, namely, to dismiss the recyclers "expropriating" or "dispossessing" them from their customary rights to collect and make some money from the waste and, instead, bringing most of it to incinerators that would produce some electricity. Critics point out, both in India and in Europe, that large scale incineration (even if disguised as "energy recovery") is an incentive to produce more waste instead of moving towards a "zero waste" objective. Out of sight and into the fire also means out of mind, at the risk however of dioxin production if the process of incineration is not adequate and proper. 
Also, after incineration, there still remains about of one third of ashes as waste that needs to be disposed of. Besides, incineration is difficult (apart from unjust and wasteful) when the organic fraction is large, as in cities where poverty is still prevalent.

Social metabolism starts with resources but ends as waste. The conflicts on waste management in Delhi are divided between, on the one side, the "traditional" recyclers and the neighbors who distrust the Ghazipur and Okhla incinerators, and on the other side, the city administration and the private sectors interested in making profits from the various stages of waste management. Schindler et al. (2012) argue that the informal sector should be incorporated into an efficient and equitable waste management system that is also environmentally sustainable. Their article is an example of action research, co-authored by the secretary of the "traditional" recyclers union, the All India Kabadi Mazdoor Mahasangh (AIKMM). The incineration alternative (called "waste to energy facility") poses a major threat to the livelihoods of waste workers because they must increasingly compete with private firms for ownership and control over recyclable waste at multiple stages. There are approximately 150,000-waste workers in Delhi, who belong to unprivileged communities and cannot easily find alternative livelihoods. These workers provide environmental services in the form of high level of recycling in working conditions that are extremely hazardous, and could and should become more just and safer. ${ }^{15}$

\section{Shipbreaking in Alang}

Finally, another type of conflict that takes place in India (as also in Bangladesh) arises from one form of waste disposal that has directly to do not so much with the internal metabolism of the Indian economy (although it contributes to it) as with what we call “Lawrence Summers' Principle". The well known economist, when he worked at the World Bank, wrote a memorandum that was leaked to the press. The Economist (8 Febr. 1992) titled the story as "Let them eat pollution". The memo recommended putting polluting industries in areas without people or where people were poor, because the costs of illness or mortality of poor people were lower than those of richer people.

The shipbreaking yards at Alang-Sosiya are practical applications of Lawrence Summers' principle. Shipbreaking is a successful case of cost shifting, or in other

\footnotetext{
${ }^{15} \mathrm{http}: / /$ www.ejolt.org/2012/02/watch-a-gaia-ejolt-video-on-waste-wars-in-delhi/ 74 
words, profit accumulation by contamination. This business shows the ugly face of globalization although in terms of economic value added and in terms of raw materials recovered, it is not so important. Over 500 big ships per year (the quantity depending on the world economic cycles) reach the beaches of Gujarat where they become grounded at high tide and are subsequently dismantled by a legion of manual workers. In 2012, Alang was again in the news when the notorious Exxon Valdez after many changes of flag (its last name was “Oriental Nicety”), reached Alang for final demolition.

Federico Demaria's work, written with activist Gopal Krishna, explains that more than $80 \%$ of international trade in goods by volume is carried by sea (Demaria, 2010). ${ }^{16}$ The shipping industry constitutes a key element in the infrastructure of the world's social metabolism. Ocean-going ships are owned and used for their trade by developed countries but are often demolished, together with their toxic materials, in relatively poor countries. Ship breaking is the process of dismantling an obsolete vessel's structure for scrapping or disposal. Ship owners and ship breakers obtain large profits shifting the environmental costs to workers, local farmers and fishermen and their families.

The international and national uneven distribution of power has led to an ecological distribution conflict. The valuation languages deployed can be analysed. The Supreme Court of India has been called on more than one occasion to decide on the costs and benefits of ship dismantling in Alang-Sosiya because of appeals through public interest litigation. Are the benefits of ship dismantling (the jobs, the recycled steel) larger than the costs to the local environment and to human health, considering that the dismantled ships carry asbestos, heavy metals? Are such costs and benefits commensurable? For instance, there was a controversy at the Indian Supreme Court in 2006 over the dismantling of the ocean liner Blue Lady, showing how the different languages of valuation expressed by different social groups clashed and how the language that expresses sustainability as monetary benefit at the national scale dominated the debate.

Here we see not only that "the poor sell cheap", and that capitalism is an economy of unpaid social and environmental costs. We also see, at a small scale, how pertinent are

\footnotetext{
${ }^{16}$ See also http://www.shipbreakingplatform.org/shipbrea_wp2011/wp-content/uploads/2012/05/120410 Ejolt1_Low2.pdf
} 
the questions that Kothari and Shrivastava ask about the costs of economic growth in India as a whole. Another growing stream of waste from North to South is electronic waste. The environmental justice organization, Toxic Links, is trying to keep track of these flows in India.

After Alang-Sosiya, the second largest ship-breaking yards are in Chittagong in Bangladesh. (The Economist, 2012), where similar controversies have arisen. The Bangladesh Environmental Lawyers Association (BELA) convinced the Supreme Court in 2009 to ban all ship breaking not meeting certain environmental standards. The industry stopped in 2010 but then pressure from the government and from the Bangladesh Ship Breakers Association led to about 150 ships being dismantled there in 2011 .

\section{Sustainability Indicators}

In India, with the exception of the HANPP, which is very bad, many other indicators are still good, per capita. Based on S.J. Singh et al. (2012), we foresee that biomass is unlikely to increase very much. But it is also unlikely to decrease as other demands for biomass substitutes for decreased fuelwood and decrease fodder for cattle. Biomass might increase because of more wood, paper and meat consumption, although at a slower rate, while agrofuels will remain marginal. Historically, it is interesting to compare the slowly moving trends in biomass from the rapid moving trends in other materials. Material flows per capita, driven by building materials (hence so many conflicts in sand mining), mineral ores for metals, and fossil fuels, will increase with income, tending towards 10 tons per capita in fifteen years at current rates of growth (still below EU average), with important internal and international impacts.

This paper has explained the methods used to count the material flows in the economy, giving the main results for the Indian economy between 1961 and 2008. We have drawn on work done by colleagues of the EJOLT project, and brief illustrations of the links between social metabolism and ecological distribution conflicts have been given. Instead of anecdotal evidence as presented in the present paper, we assure that what is needed is a historical reconstruction of hundreds or indeed thousands of environmental conflicts in India (classified as biomass conflicts, mining and fossil fuels conflicts, 76 
waste disposal conflicts). This data thus ought to show whether these conflicts increase in number and intensity with the growth of the social metabolism, what the outcomes have been, and how they have been solved; i.e. by technological modernization or by repression, displacement, criminalization of activists, or by monetary compensation for the "externalities". In this light, the historical significance of movements of environmental resistance has been analyzed by historians of India on many occasions already.

In a pioneering article in 1988 linking ecological economics and political ecology, Jayanta Bandyopahdyay and Vandana Shiva, who have already published remarkable articles against eucalyptus plantations, provided a theory on what they called the Political Economy of Environmental Movements. Citing repeatedly Nicholas Georgescu-Roegen, they showed the incapacity of economic theory to deal with resource exhaustion and with pervasive externalities, and they ridiculed Solow's phrase dated 1974 that the economy could get along without natural resources. Furthermore, they pointed out that environmental movements made the externalities visible (as Enrique Leff had written in 1986 in Ecologia y Capital), and asserted that care of the environment was not a "luxury of the rich" and explained (following N.S. Jodha) that human survival in India was directly dependant, for many people, on the direct utilization of natural resources held in common. They listed a number of historical and current movements such as the Chipko and Appiko movements against deforestation and tree plantations, the movements against limestone quarries in the Doon Valley and in Almora and Pithoragath in Uttarakhand, the early successful movements against bauxite mining in the Gandhamarardan hills in Odisha against the state company BALCO (Bharat Aluminium Company), the conflicts on coal mining in Singrauli ("the energy capital of the country", a terrible place), and also the movements attempting to stop dams whether in the Silent Valley in Kerala (whose motivation was biodiversity conservation rather than the survival of the people), the Tehri Dam in the Himalaya, and other movements fighting submersion in Bedthi, Inchampalli, Bhopalpatnam, Narmada, Koel-Karo, Bodhghat. Among the authors quoted in this study figures Medha Patkar (Bandyopadhyay \& Shiva, 1988). 
Current conflicting coal mining cases include Jharia in Jarkhand where another state company, Bharat Coking Coal (BCCL), operates the collieries in a landscape of underground fires and land subsidence, or the Mahanadi Coal Fields in Orissa. In Jharkhand, UCIL (Uranium Corporation of India) mines uranium, and an outstanding documentary, "Buddha weeps at Jadugoda", shows birth malformations negated by the company and corroborated by Xavier Dias. Iron mining in Bailadila in Chhatisgarh is another socio-environmental disaster, narrated as the preceding cases in one of the chapters of The Caterpillar and the Mahua Flower edited in 2007 by Rakesh Kanshian. ${ }^{17}$ The visual metaphor behind the book's title refers to the mahua tree of the central and eastern zone of India which provides a nice drink for tribal peoples, while the "caterpillar" here does not refer to a life form but, instead, to the fossil-fuel driven machine.

There is much accumulated knowledge on socio-environmental conflicts coming from "activist knowledge" since the 1980s in the Centre for Science and Environment's citizens' reports of 1982 and 1985, and we assure that there must also exist an enormous variety of regional sources. What would now be required are studies at state or regional levels of the trends in social metabolism (at least, the Domestic Material Extraction and the Physical Trade Balances), including also historical statistics on the increase in the HANPP, on water use, on energy flows. This enhanced data would thus help to see the connections to changing patterns of environmental conflicts.

\section{Climate Change and Climate Justice}

The concentration of carbon dioxide in the atmosphere is still increasing at 2 ppm per year. It was $300 \mathrm{ppm}$ when Arrhenius first wrote on the enhanced greenhouse effect, and it is now at $400 \mathrm{ppm}$, with no prospect of international agreement on reduction of emissions since the UN gave up this initiative after the failed Copenhagen meeting of 2009.

Per capita carbon emissions and (therefore) the ecological footprint, amount in India to only one third of the global mean, and about an eighth of industrialised economies. The

17 Available at http://www.panossouthasia.org/pdf/Caterpillar\%20and\%20the\%20Mahua\%20Flower.pdf 
feeling of injustice expressed by Anil Agarwal and Sunita Narain in their influential booklet of 1991, Global warming in an unequal world: a case of environmental colonialism. The subsequent movements claim that the "ecological debt" (and Climate Justice) also had resonance in other countries of the "South", although they have not succeeded in shaming the rich countries in paying back such liabilities or in slowing down their growth.

Internationally, India's government and citizens claim with reason that the country has, by its low per capita consumption, made a contribution to world sustainability. With a population that is almost one-fifth of the global total, India currently uses only $10 \%$ of the global supply of material resources (in terms of tonnage) and $6 \%$ of global primary energy supply. Even though India's per capita level of resource use and emissions are strikingly modest, India's requirements are not negligible at present. Internationally, an India whose carbon dioxide emissions per capita would increase from two tons before 1990 to a European average of ten tons, would have (ceteris paribus) a most significant impact on world climate.

Given the fact that India might hold nearly one fifth of humanity when world population (optimistically) peaks by 2050 at 8.5 billion people, one can easily foresee the non negligible impact that the social metabolism of the growing Indian economy (largely fuelled by coal) will have on world environmental pressures. To give room for India, China and the rest of the world, the rich countries should decrease their social metabolism, and this could be hopefully be achieved by moving towards a steady-state economy preceded by a period of moderate degrowth in material and energy use. There is a possible alliance between the small décroissance (degrowth), and post-Wachstum, "prosperity without growth" movements in some Northern countries who ask the question, how much should a person consume? and the large and growing world movements for environmental justice (Martinez-Alier, 2012)

\section{Conclusion}

India should take pride in the fact that its material throughput per person is still at 5 tons per year while the European Union is at 15 tons. But such numbers are irrelevant in 
actual political life and such pride is largely absent. On the contrary, there is emphasis in many circles in India on the glories of economic growth, leaving aside the metabolic implications. However, the links from social metabolism to resource extraction and waste disposal conflicts at different scales are a reality that we have only superficially explored in this article. The growing social metabolism causes internally great environmental and human livelihood losses, and also, increasingly negative external effects at world level.

One should look at the historically changing social actors and types of resistance in such conflicts, as has been done in historical work on ecological distribution conflicts (as when Ramachandra Guha compared Garhwal and Kumaun in The Unquiet Woods), while also looking at the changing valuation languages deployed. For instance, when and why did the Kanchan Chopra committee at the prompting of the Supreme Court, establish methodologies to count the NPV (Net Present Value) of destroyed forests, and what have been its effects? Indeed, has the Supreme Court the power to impose the single language of valuation of the NPV, and at which discount rate? On the contrary, what are the regional and historical patterns of development projects stopped in India by the use of "sacredness"? (Temper and Martinez-Alier, 2013). Or, for instance, has the use of adivasi forest rights been increasingly effective to stop development projects as the use of Convention 169 of ILO has been in Latin America? Such studies would represent important contributions to the history of the global environmental justice movement where India is such a big actor.

Since the 1970s and 1980s authors and groups in India have taken part and have sometimes led movements for environmental justice at local, national and international levels. There is now a global Climate Justice movement, coupled with a growing Hydric Justice (Water Justice) movement, plus networks with strong Indian presence sharing strategies in the combat against biopiracy or against particularly aggressive international firms (Coca Cola in water extraction). Such environmental justice movements contribute to democracy and they constitute the strongest forces for environmental sustainability.

On the contrary, there is too much emphasis among policy makers on hypothetical economic valuations of environmental damages and on economic instruments, and too 
little on this great tide of environmental justice. When the stakeholders in such conflicts do not insist so much on economic compensation for externalities as on different local alternatives (as explained in the second part of Shrivastava's and Kothari's book, 2012) they join those in Latin America searching for a buen vivir or Sumak Kawsay, perhaps translatable as aparigraha, a voluntary simplicity rooted in local social values, and they also join and support those few in rich countries who preach a moderate décroissance (degrowth) leading to a "steady state economy" or a "prosperity without growth".

\section{WORKS CITED}

ASHER, MANSHI (2009). "Striking While the Iron is Hot: A Case Study of the Pohang Steel Company's (POSCO) Proposed Project in Orissa". National Centre for Advocacy Studies.

Bandyopadhyay, J. \& Shiva, V. (1988). "Political Economy of Ecology Movements", Economic and Political Weekly, 23(24), June: 1223-1232.

D’Souza, Rohan (2012). Environment, Technology and Development. Critical and Subversive Essays, New Delhi: Orient Black Swan.

DEMARIA, FEDERICO (2010). "Shipbreaking at Alang-Sosiya: an ecological distribution conflict”, Ecological Economics, 70 (2).

Editorial (2012). "Games Vedanta Plays", Economic and Political Weekly, 22 Dec. http://www.epw.in/system/files/pdf/2012_47/51/Games_Vedanta_Plays.pdf

FERNANDES, W. \& ASIF, M. (1997). "Development Induced Displacement and Rehabilitation in Orissa, 1951 to 1995: a Database on its Extent and Nature", New Delhi: Indian Social Institute: 72- 80.

GRINEVALD, JACQUES (1976). "La Révolution carnotienne. Thermodynamique, économie et idéologie", Revue européenne des sciences sociales et cahiers Vilfredo Pareto, 36: 39-79.

GuHA, R. \& J. MARTINEZ-Alier (1997). Varieties of Environmentalism. Essays North and South, Delhi: Oxford U. P.

Hall, C. A. S., C. J. Cleveland, R. K. Kaufmann (1986). Energy and Resource Quality. The Ecology of the Economic Process. New York: Wiley Interscience.

HORNBORG, A (1998). "Towards an Ecological Theory of Unequal Exchange: Articulating World System Theory and Ecological Economics", Ecological Economics 25: 127-136.

HORNBORG A (2007). "Footprints in the Cotton Fields: The Industrial Revolution as Time-Space Appropriation and Environmental Load Displacement" in A.Hornborg, J.McNeill, J. Martinez-Alier (eds) Rethinking Environmental History. World-System History and Global Environmental Change, Altamira Press. 
Kosoy, N., \& E. Corbera (2010). "Payments for Ecosystem Services as Commodity Fetishism", Ecological Economics, 69: 1228-36.

MARTINEZ-AliER, J. (1987). Ecological Economics: Energy, Environment and Society, Blackwell, Oxford.

MARTINEZ-AliER, J. (1995). "The Environment as a Luxury Good or "too poor to be green'?", Ecological Economics, 13 (1): 1-10.

Martinez-Alier, J. (2005). The Environmentalism of the Poor. A Study of Ecological Conflicts and Valuation. Delhi: Oxford U.P.

MARTINEZ-Alier, J. (2011). "The EROI of Agriculture and its Use by Via Campesina", Journal of Peasant Studies, 38(1): 145-160.

MartineZ-Alier, J. (2012). "Environmental Justice and Economic Degrowth: an Alliance Between Two Movements", Capitalism Nature Socialism 23: 51-73.

MishrA, D.K. (2011). "Behind Dispossession: State, Land Grabbing and Agrarian Change in Rural Orissa". Paper presented at the International Conference on Global Land Grabbing, 6-8 April.

NAI AZADI, monthly journal of Azadi Bachao Andolan, Oct-Dec 2012, special issue in memory of Prof. Banwari Lal Sharma, issued by the Swaraj Vidyapith in Allahabad.

NorgaARD, R. B. (1994). Development Betrayed: The End of Progress and a Coevolutionary Revisioning of the Future. London: Routledge.

Padel, F., AND S. DAS (2010). Out of this Earth: East India Adivasis and the Aluminium Cartel (foreword by Arundhati Roy), Hyderabad: Orient Black Swan.

Pimentel, D., ET AL. (1973). "Food Production and the Energy Crisis", Science 182 (4111): 443-449.

POLANYI, KARL (1944). The Great Transformation, New York: Rinehart.

RANGAJARAN, MAHESH \& K. SiVARAMAKRISHNAN (EDS) (2012). India's Environmental History: Colonialism, Modernity and the Nation, Ranikhet: Permanent Black.

SACHS, W., (ED) (1991). The Development Dictionary: a Guide to Knowledge as Power, Zed Books, London, 1991.

Schindler, Seth, Demaria, Federico, Pandit, Shashi B (2012). "Delhi's Waste Wars", Economic and Political Weekly, XLVII (42): 18-2.

Sen, Amartya (1999). Development as Freedom, Oxford: Oxford U.P.

Singh, S.J., F. Krausmann F., S. Gingrich, H. Haberl, K-H. Erb, P, LanZ, J. MARTINEZ-Alier, L. TEMPER (2012). "India's Biophysical Economy, 19612008: Sustainability in a National and Global Context", Ecological Economics, 72: 60-69. 
Singh A.A., Mahongnao M., Demaria F., Krishna V.V. (2012). "Illegal Sand Mining Conflicts in India", EJOLT Factsheet by CSPP, JNU. http://www.ejolt.org/wordpress/wp-content/uploads/2012/11/Mining-Report$\underline{\text { low.pdf }}$

Shrivastava, Kumar Sambhav, (2011). "A Swami and Sand Mining", Down To Earth, July 15. http://www.downtoearth.org.in/content/swami-and-sand-mafia

Srivastava, Aseem \& ASHISH Kothari (2012). Churning the Earth: the Making of Global India, Delhi: Penguin.

TEMPER, LEAH \& J. MARTINEZ-Alier (2007). "Is India too poor to be green?", Economic and Political Weekly, XLII (17).

Temper, LeAH \& J. MartineZ-Alier (2013). "The God of the Mountain and Godavarman: Net Present Value, Indigenous Territorial Rights and Sacredness in a Bauxite Mining Conflict in India”, Ecological Economics, 96: 79-87.

TEEB Foundation (2008). The Economics of Ecosystems and Biodiversity: An Interim Report. Brussels: European Commission.

TEEB FoundATION (2010). The Economics of Ecosystems and Biodiversity: Ecological and Economic Foundations. Pushpam Kumar (ed). London: Earthscan.

THE ECONOMIST (2012). "Ship Breaking in Bangladesh. Hard to Break Up”, 27 October. 